Jurnal Farmasi Galenika (Galenika Journal of Pharmacy) (e-Journal) 2020; 6(2): 269 - 279

ISSN: 2442-8744 (electronic); 2442-7284 (printed)

Journal Homepage: https://bestjournal.untad.ac.id/index.php/Galenika

DOI: $10.22487 / j 24428744.2020 . v 6.12 .15092$

\title{
Perbandingan Basis Salep Hidrokarbon dan Absorpsi Terhadap Aktivitas Antibakteri Ekstrak Kasar Bromelin Dari Bonggol Nanas
}

\section{(Comparison of Hydrocarbon Ointment Bases and Absorpsion on the Antibacterial Activity of Bromelin Crude Extract from Pineapple Tuber)}

\author{
Barmi Hartesi $^{1 *}$, Desi Sagita ${ }^{2}$, Helsa Raudatul Qalbi ${ }^{1}$ \\ ${ }^{1}$ Jurusan Farmasi, Sekolah Tinggi Ilmu Kesehatan (STIKES) Harapan Ibu Jambi, Indonesia. \\ ${ }^{2}$ Jurusan Farmasi, Universitas Adiwangsa, Jambi, Indonesia. \\ *E-mail: barmi.hartesi@gmail.com
}

Article Info:

Received: 1 Mei 2020

in revised form: 11 Mei 2020

Accepted: 28 September 2020

Available Online: 30 September 2020

Keywords:

Antibacterial

Ointment Base

Pineapple Stems

Bromelain

Corresponding Author:

Barmi Hartesi

Jurusan Farmasi

Sekolah Tinggi Ilmu Kesehatan

Harapan Ibu

Jambi

36132

Indonesia

email: barmi.hartesi@gmail.com

\section{ABSTRACT}

The pineapple tuber contains bromelain enzyme which is able to inhibit the growth of Staphylococcus aureus and Pseudomonas aeruginosa causing skin infections. The topical preparation that good for treating skin infections is ointments. Ointments have two type of bases such as hydrocarbon and absorption base. This study aims to compare the comparison of ointment bases having antibacterial activity of Staphylococcus aureus and Pseudomonas aeruginosa. This research used experimental methods. The bromelain enzyme was extracted and purified with ammonium sulfate and then dialyzed. The bromelain enzyme with a concentration of $4 \%$ was formulated into ointment preparation with a base of hydrocarbons (F1, F2) and absorption base (F3, F4). Each formula was evaluated for organoleptic, homogenity, $\mathrm{pH}$, spreadability, irritation test, stability and antibacterial activity. The results showed that all formulas with hydrocarbon base and absorbent base types met good topical preparation requirements, that are semi-solid, homogeneous, having a $\mathrm{pH}$ range of 4.5 6.5 , stable during storage and not irritating on the skin. However, ointments based on hydrocarbons have the best antibacterial activity when compared to absorption base ointments. Formula 2 with a base of hydrocarbons have strong antibacterial activity against Staphylococcus aureus and Pseudomonas aeruginosa which is the best among the other formulas.

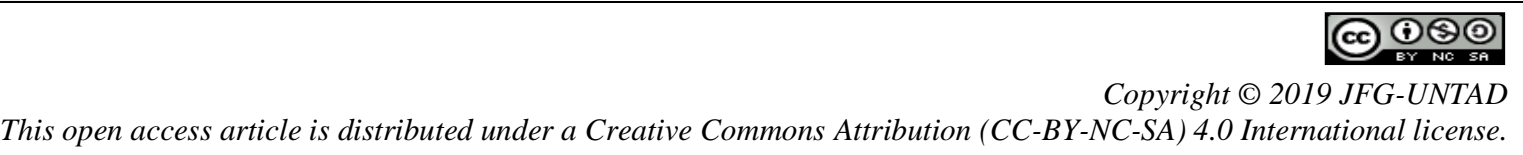

How to cite (APA $6^{\text {th }}$ Style):

Hartesi, B., Sagita, D., Qalbi, H. R. (2020). Perbandingan Basis Salep Terhadap Aktivitas Antibakteri Ekstrak Kasar Bromelin Dari Bonggol Nanas. Jurnal Farmasi Galenika :Galenika Journal of Pharmacy (e-Journal), 6(2), $269-279$. doi:10.22487/j24428744.2020.v6.i2.15092 


\begin{abstract}
ABSTRAK
Bonggol nanas mengandung enzim bromelin yang mampu menghambat pertumbuhan bakteri Staphylococcus aureus dan Pseudomonas aeruginosa penyebab infeksi kulit. Sediaan topikal yang baik untuk mengobati infeksi kulit adalah salep. Salep memiliki beberapa tipe basis seperti basis hidrokarbon dan basis absorpsi. Penelitian ini bertujuan untuk mendapatkan perbandingan basis salep hidrokarbon dan absorpsi yang memiliki aktivitas antibakteri Staphylococcus aureus dan Pseudomonas aeruginosa. Penelitian ini menggunakan metode eksperimental. Enzim bromelin di ekstraksi dan dimurnikan dengan amonium sulfat dan di dialisis. Enzim bromelin dengan konsentrasi $4 \%$ tersebut diformulasikan menjadi sediaan salep dengan basis hidrokarbon (F1),(F2) dan basis absorpsi (F3),(F4). Setiap formula salep dievalusi (Organoleptis, homogenitas, pH, daya sebar, uji iritasi, stabilitas dan aktivitas antibakteri). Hasil penelitian menunjukkan semua formula dengan tipe basis hidrokarbon dan basis absorpsi memenuhi persyaratan sediaan topikal yang baik yaitu berbentuk setengah padat, homogen, memiliki pH dengan rentang 4,5-6,5, stabil selama penyimpanan dan tidak mengiritasi kulit. Akan tetapi sediaan salep dengan basis hidrokarbon yang paling baik aktivitas antibaketerinya jika dibandingkan dengan sediaan salep basis absorpsi. Formula 2 dengan basis hidrokarbon memiliki aktivitas antibakteri Staphylococcus aureus dan Pseudomonas aeruginosa. yang paling baik diantara formula lainnya dengan kategori kuat.
\end{abstract}

Kata kunci: Antibakteri, Basis Salep, Bonggol Nanas, Bromelin.

\title{
PENDAHULUAN
}

Tanaman Nanas (Ananas comosus L. Merr) merupakan salah satu tanaman yang banyak tumbuh di Indonesia khususnya di Provinsi Jambi yang mencapai 144.896 ton pada tahun 2014 (Ibrahim \& Mutia, 2015). Salah satu kandungan dalam buah nanas adalah bromelin yang merupakan enzim proteolitik golongan sufrihidil. Bromelin memiliki aktivitas untuk menghambat pertumbuhan bakteri gram positif maupun gram negatif (Masri, 2014). Staphylococcus aureus dan Pseudomonas aeruginosa merupakan bakteri yang banyak terdapat pada kulit.

Penelitian terdahulu menyatakan ekstrak dari nanas dapat menghambat pertumbuhan bakteri dengan konsentrasi $1000 \mu \mathrm{g} / \mathrm{ml}$ terhadap bakteri Pseudomonas aeruginosa dengan diameter zona hambat 20 mm dan Staphylococcus aureus $23 \mathrm{~mm}$ (Ashik Ahamed et al., 2016). Bentuk sediaan antibakteri untuk kulit yang baik adalah salep.Salep terdiri dari basis salep yang bersifat inert dan tidak mempengaruhi efek terapi dari zat aktif. Basis salep yang biasa digunakan adalah basis hidrokarbon dan basis absorpsi(Naibaho et al., 2013).Penelitian lainnya mengenai formulasi salep dengan menggunakan berbagai tipe basis yang berbeda pada ekstrak acalyphaIndica (tanaman akar kucing)menjelaskan bahwa tipe basis serap memiliki sifat dan karakteristik yang lebih baik dibandingkan salep dengan tipe basis hidrokarbon. Hal ini dikarena basis hidrokarbon yang mengandung ekstrak acalyphaIndica kurang stabil selama penyimpanan (Nagajyothi et al., 2014)

Penelitian lain yang dilakukan untuk melihat pengaruh tipe basis salep dari ekstrak daun kemangi terhadap infeksi bakteri Staphylococcus aureus, menjelaskan bahwa salep dengan basis hidrokarbon memiliki daya antibakteri lebih besar dibandingkan dengan basis lainnya yang dilihat dari penyembuhan infeksi pada kulit kelinci. Hal ini dikarenakan terjadinya efek hidrasi kulit yang dapat mempengaruhi absorpsi obat pada kulit. Basis hidrokarbon memiliki efek dalam menghidrasi kulit sehingga dapat meningkatkan absorpsi bahan obat pada sediaan salep. Sedangkan pada basis absorpsitidak memiliki derajat penutupan pada kulit sebaik basis hidrokarbon sehingga absorpsi obat tidak begitu cepat (Naibaho et al., 2013). Penelitian ini bertujuan untuk mengetahui perbandingan basis salep hidrokarbon dan absorpsi terhadap aktivitas antibakteri ekstrak kasar bromelin dari bonggol nanas (Ananas comosus L. Merr). 


\section{METODE PENELITIAN}

\section{Alat dan Bahan}

Alat-alat yang digunakan yaitu timbangan analitik (Shimadzu®), blender (Miyako®), magnetic stirrer(Ika®), sentrifuse(Hettich $\AA$ ), membrane semipermiabel (Sigma Aldrich $®$ ) alat-alat gelas (Pyrex $®)$, autoklaf (HIRAYAMA®), Laminar Air Flow (KOJAIR $\left.{ }^{\circledR}\right)$, inkubator (Memmert $\left.{ }^{\circledR}\right)$, oven (Memmert $\AA$ ), spektrofotometer, vortex (Thermo®), lemari pendingin (LG®), hot plate (MITSEDA®), dan pipet mikro (Eppendorf Research plus®). Bahan-bahan yang dipakai dalam penelitian ini yaitu bonggol buah nanas muda, dapar fosfat $\mathrm{pH} 7,0$, larutan $\mathrm{NaCl}$ fisiologis, aquadestilata, ammonium sulfat, media Nutrient Broth (Oxoid), media Nutrient Agar (Oxoid), cakram kloramfenikol 0,3\% (Oxoid), vaselin album (Brataco), paraffin padat (Brataco), paraffin cair (Brataco), cera alba (Brataco), cetyl alkohol (Brataco), adepslanae (Brataco), lanolin, EDTA,NaOH, $\mathrm{KH}_{2} \mathrm{PO}_{4}$, TCA dan Natrium Karbonat.

\section{Metode}

Penelitian ini merupakanpenelitian eksperimental. Dimulai dari penyiapan alat, pengambilan sampel, proses ekstraksi dan purifikasi enzim, penetapan kadar enzim bromelin, proses pembuatan sediaan salep dan evaluasi sediaan yang telah di buat. Evaluasi sediaan meliputi uji organoleptik, uji pH, uji daya sebar, uji homogenitas, uji iritasi, uji antibakteri dan uji stabilitas

\section{Pengambilan Sampel}

Buah nanas yang diperlukan dalam penelitian sebanyak $5 \mathrm{~kg}$ yang di ambil dari desa Tangkit kabupaten Muaro Jambi, Jambi. Proses ekstraksi dimulai dengan menimbang $5 \mathrm{~kg}$ bonggol buah nanas kemudian di rajang. Setelah itu bonggol buah nanas di tambahkan dapar fosfat $\mathrm{pH}$ 7,0 kemudian di blender. Hasil dari proses blender di saring dan di dapat suatu fitrat. Filtrat tersebut di sentrifugasi dengan kecepatan $4000 \mathrm{rpm}$ selama 10 menit. Supernatan dari proses sentrifugasi kemudian di timbang yang merupakan ekstrak kasar dari bromelin(Masri, 2014).

\section{Proses Pemurnian}

Proses pemurnian sebagian (parsial purified) dari ekstrak kasar bromelin dilakukan dengan menambahkan ammonium sulfat sedikit demi sedikit pada suhu $4^{\circ} \mathrm{C}$ selama 24 jam sambil diaduk menggunakan magnetic stirrer. Larutan yang diperoleh selanjutnya disentrifugasi menggunakan kecepatan $4000 \mathrm{rpm}$ selama 10 menit sehingga di dapat endapan berupa enzim bromelin. Endapan tersebut didialisis dengan membran dialisa selama 16 jam, hasil dialisis disentrifugasi kembali sehingga didapat endapan ekstrak kasar bromelin yang dimurnikan sebagian (parsial purified)(Masri, 2014).

\section{Penentuan Unit Aktivitas}

Penentuan unit aktivitas enzim bromelin dalam bonggol buah nanas menggunakan substrat kasein yang terdiri dari $2 \%$ kasein dalam dapar posfat $0,1 \mathrm{M}$ dengan $\mathrm{pH} 7,5$. Sebanyak $50 \mu \mathrm{L}$ sampel di sentrifugasi dengan larutan buffer kasein sebanyak $0,625 \mathrm{ml}$ dan di diamkan selama 10 menit. Tambahkan TCA (Trichloroacetic acid) $1 \mathrm{M}$ sebanyak 1,25 ml. Lakukan proses inkubasi selama 10 menit dengan suhu $25^{\circ} \mathrm{C}$ selanjutnya di sentarifugasi selama 20 menit dengan kecepatan $4000 \mathrm{rpm}$ untuk mendapatkan filtrat dari campuran tersebut. $1 \mathrm{ml}$ dari filtarat di encerkan menggunakan dapar fosfat $\mathrm{pH}$ 7,5 sebanyak $5 \mathrm{ml}$. Untuk menentukan kurva standar tirosin, digunakan 5 konsentrasi yang berbeda yaitu 100ppm, $80 \mathrm{ppm}, 60 \mathrm{ppm}, 40 \mathrm{ppm}$ dan $20 \mathrm{ppm}$. Ukur absorbansi dengan menggunakan tirosin sebagai pembanding yang memiliki panjang gelombang $280 \mathrm{~nm}$ menggunakan Spektrofotometer UV(Soares et al., 2012). 


\section{Uji Aktivitas Antibakteri Ekstrak Kasar Bromelin}

Uji antibakteri dilakukan dengan metode sumur. Media Nutrient Agar yang telah steril dituangkedalam 24 cawan petri. Masing - masing cawan petri dimasukkan media $\pm 20 \mathrm{ml}$ dan dibiarkan dingin serta memadat. Suspensi bakteri Staphylococcusaureus dan Pseudomonas aeruginosa yang diinokulasikan pada seluruh permukaan media dengan menggunakan batang L. Pada masingmasing media tersebut dibuat 4 sumur secara aseptis dengan pipa pelubang untuk uji antibakteri salep ekstrak kasar bromelin yang dimurnikan sebagian dari bonggol buah nanas. Untuk uji aktivitas antibakteri ekstrak kasar bromelin yang dimurnikan sebagian konsentrasi 3\%, 4\%, kontrol positif (+) yaitu cakram kloramfenikol, dan kontrol negatif (-) yaitu dapar fosfat.

\section{Formulasi Basis Salep}

Formulasi basis salep dimulai dengan menimbang semua basis salep sesuai dengan formula yang terdapat pada tabel 1 .

Basis salep hidrokarbon

Formula 1 :Cera alba, parafin padat, dan cetil alkohol di lebur pada suhu $50^{\circ} \mathrm{C}$ dengan waterbath. Setelah melebur sempurna, di masukkan kedalam lumpang panas. Kedalam lumpang tersebut di tambahkan vaselin album dan digerus perlahan hingga dingin dan homogen.

Formula 2 :Parafin padat di lebur pada suhu $50^{\circ} \mathrm{C}$ dengan waterbath. Setelah melebur sempurna, di masukkan kedalam lumpang panas. Kedalam lumpang tersebut di tambahkan vaselin album dan parafin cair dan digerus perlahan hingga basis salep dingin dan homogen.

Basis salep absorpsi

Formula 3 :Parafin padat dan cetyl alkohol di lebur pada suhu $50^{\circ} \mathrm{C}$ dengan waterbath. Setelah melebur sempurna, di masukkan kedalam lumpang panas. Kedalam lumpang tersebut ditambahkan vaselin album dan lanolin dan digerus perlahan hingga basis salep dingin dan homogen.

Formula 4 : Lanolin dimasukkan kedalam lumpang dan ditambahkan aquadest sedikit demi sedikit perlahan hingga basis homogen.

Tabel 1. Formula Basis Salep

\begin{tabular}{lcccc}
\hline & \multicolumn{2}{c}{ Basis Hidrokarbon } & \multicolumn{2}{c}{ Basis Absorpsi } \\
\cline { 2 - 5 } Nama Bahan & F1 & F2 & F3 & F4 \\
\hline Cera alba (g) & 2 & - & - & - \\
Parafin padat $(\mathrm{g})$ & 3 & 5 & 2 & - \\
Cetyl alkohol $(\mathrm{g})$ & 5 & - & 5 & - \\
Vaselin album & 90 & 55 & 85 & - \\
Parafin cair $(\mathrm{g})$ & - & 40 & - & - \\
Lanolin $(\mathrm{g})$ & - & - & 8 & 70 \\
Aquadest $(\mathrm{g})$ & - & - & - & 30 \\
Berat Total $(\mathrm{g})$ & 100 & 100 & 100 & 100 \\
\hline
\end{tabular}

Pembuatan Salep

Ekstrak kasar bromelin yang dimurnikan sebagian di pilih sesuai dengan konsentrasi yang paling kuat memiliki aktivitas antibakterinya antara kosentrasi 3\% atau $4 \%$ (Tabel 2). Basis salep di masukkan sedikit demi sedikit kedalam lumpang. Ekstrak dan BHT (Butylated Hydroxytoluene) di tambahkan 
sedikit demi sedikit selanjtnya digerus hingga homogen. Salep dimasukkan ke dalam pot salep untuk di evaluasi.

Tabel 2. Formula Salep

\begin{tabular}{ccccccccc}
\hline Zat & $\mathbf{F 1}(\% \mathbf{b} / \mathbf{b})$ & $\mathbf{F 2}(\% \mathbf{b} / \mathbf{b})$ & \multicolumn{2}{c}{$\mathbf{F 3}(\% \mathbf{b} / \mathbf{b})$} & \multicolumn{2}{c}{$\mathbf{F 4}(\% \mathbf{b} / \mathbf{b})$} \\
\cline { 2 - 9 } & $\mathbf{A}$ & $\mathbf{B}$ & $\mathbf{A}$ & $\mathbf{B}$ & $\mathbf{A}$ & $\mathbf{B}$ & $\mathbf{A}$ & $\mathbf{B}$ \\
\hline $\begin{array}{c}\text { Ekstrak Kasar } \\
\text { Bromelin }\end{array}$ & 0 & $\mathrm{X}$ & 0 & $\mathrm{X}$ & 0 & $\mathrm{X}$ & 0 & $\mathrm{X}$ \\
$\begin{array}{c}\text { BHT } \\
\text { Basis Salep }\end{array}$ & 0,1 & 0,1 & 0,1 & 0,1 & 0,1 & 0,1 & 0,1 & 0,1 \\
$\begin{array}{c}\text { Dicukupkan } \\
\text { Hingga }\end{array}$ & 100 & 100 & 100 & 100 & 100 & 100 & 100 & 100 \\
\hline
\end{tabular}

\section{Keterangan :}

$\mathrm{X}=$ Kosentrasi yang terbaik

$\mathrm{A}=$ Formula Basis Salep

$\mathrm{B}=$ Formula Salep dengan zat aktif ( Ekstrak Kasar Bromelin )

\section{Evaluasi Salep}

\section{Uji Organoleptis}

Uji organoleptis yaitu melihat bentuk, warna dan bau dari sediaan salep secara visual (Naibaho et al., 2013).

\section{Uji Homogenitas}

Uji homogenitas dilakukan dengan cara meletakkan salep secukupnya pada dua objec glass kemudian dilihat apakah terdapat gumpalan pada salep (Naibaho et al., 2013).

Uji pH

Uji $\mathrm{pH}$ menggunakan alat $\mathrm{pH}$ meter. Proses pengujian $\mathrm{pH}$ di mulai dengan mengkalibrasi $\mathrm{pH}$ terlebih dahulu dengan cara mencelupkan elektroda $\mathrm{pH}$ dan stik temperatur kedalam larutan buffer fosfat $\mathrm{pH}$ 7.01 dan buffer fosfat $\mathrm{pH}$ 4.01. 1 gram salep di timbang dan diencerkan dengan $10 \mathrm{ml}$ aquadest. Elektroda $\mathrm{pH}$ dan stik temperatur kemudian dimasukkan kedalam sediaan salep yang sudah diencerkan dan dibaca pH pada bagian monitor (Naibaho et al., 2013).

\section{Uji Daya Sebar}

Uji daya sebar salep dilakukan dengan cara menimbang 1 gram sedian salep dan diletakkan diatas plastik kaca. Kemudian di berikan beban bertahap secara bergantian yaitu $2 \mathrm{~g}$, 4g dan $6 \mathrm{~g}$. Ukur diameter penyebaran yang terbentuk (Hasyim et al., 2012).

\section{Uji Iritasi}

Uji iritasi menggunakan 30 responden dengan syarat yaitu tidak sedang menggunakan obat. Usia sukarelawan sukarelawan terdiri dari anak-anak (5 - 11 tahun) sebanyak 10 orang, remaja (12 - 25 tahun) sebanyak 10 orang, dan dewasa (26 - 45 tahun) sebanyak 10 orang dengan menggunakan metode tempel tertutup. Pengujian ini dilakukan dengan mengoleskan 0,1 gram salep pada lengan bagian dalam dan ditutup dengan kain kasa selama 24 jam. Amati gejala iritasi yang timbul (Rahim,Farida., Aria,Mimi., Aji, 2011). 
Uji Stabilitas

Uji stabilitas di lakukan dengan cara meyimpan salep selama 28 hari pada kondisi suhu yang berbeda yaitu $4^{\circ} \mathrm{C}$, suhu ruangan dan $40^{\circ} \mathrm{C}$. Lihat perubahan organoleptik, $\mathrm{pH}$ sediaan, daya sebar dan aktivitas antibakteri (Nagajyothi et al., 2014).

Uji Aktivitas Antibakteri Salep

Salep dimasukkan kedalam sumuran pada media sebanyak $10 \mathrm{mg}$ formula basis salep (F1a, F1b, F2a, F2b, F3a, F3b, F4a dan F4b), kontrol positif (+) yaitu salep yang berada dipasaran, dan kontrol negatif (-) merupakan basis salep. Inkubasi cawan petri selama 24 jam pada suhu $37{ }^{\circ} \mathrm{C}$. Lakukan pengukuran zona hambat dari ekstrak kasarbromelin dan salep antibakteri yang dimurnikan sebagian dari bonggol buah nanas.

\section{HASIL DAN PEMBAHASAN}

Sampel yang digunakan adalah bonggol nanas mentah karena bonggol nanas memiliki kandungan enzim bromelin yang lebih banyak dibandingkan pada kulit nanas (Masri, 2013). Ekstrak bromelin dimurnikan sebagian yang didapat dari serangkaian proses ekstraksi dan pemurnian sebanyak $21 \mathrm{ml}$ atau 49.07 gram yang diperoleh dari $5 \mathrm{~kg}$ bonggol buah nanas mentah. Hasil pengukuran unit aktivitas bromelin dari bonggol nanas dapat dilihat pada tabel 3.

Tabel 3. Hasil Pengukuran Unit Aktivitas Bromelin Bonggol Nanas

\begin{tabular}{ccc}
\hline Persamaan Regresi & Rata-rata Absorban & $\begin{array}{c}\text { Unit Aktivitas Bromelin } \\
\mathbf{U} / \mathbf{~ m L}\end{array}$ \\
\hline $\mathrm{y}=0,0072 \mathrm{x}-0,0175$ & 0,74203 & $210,9804 \mathrm{U} / \mathrm{mL}$
\end{tabular}

Enzim bromelin memiliki aktivitas antibakteri terhadap bakteri Staphylococcus aureus dan Pseudomonas aeruginosa. Pengujian aktivitas antibakteri untuk konsentrasi enzim 3\% dan $4 \%$. Kontrol (+) yang digunakan adalah kloramfenikol 0,3\% dan kontrol (-) berupa dapar fosfat, dikarenakan dapar fosfar merupakan pelarut yang digunakan untuk pemurnian ekstrak bonggol buah nanas. Bromelin merupakan enzim yang bersifat proteolitik sehingga mampu menghidrolisis rantai protein pada bakteri(Ashik Ahamed et al., 2016). Jika dilihat pada Gambar 1, Konsentrasi ekstrak bromelin $4 \%$ memiliki aktivitas yang lebih tinggi dibandingkan konsentrasi 3\%, sehingga konsentrasi yang dipilih untuk dibuat sediaan salep adalah konsentrasi $4 \%$. Konsentrasi $4 \%$ mimiliki aktivitas antibakteri dengan kategori kuat.

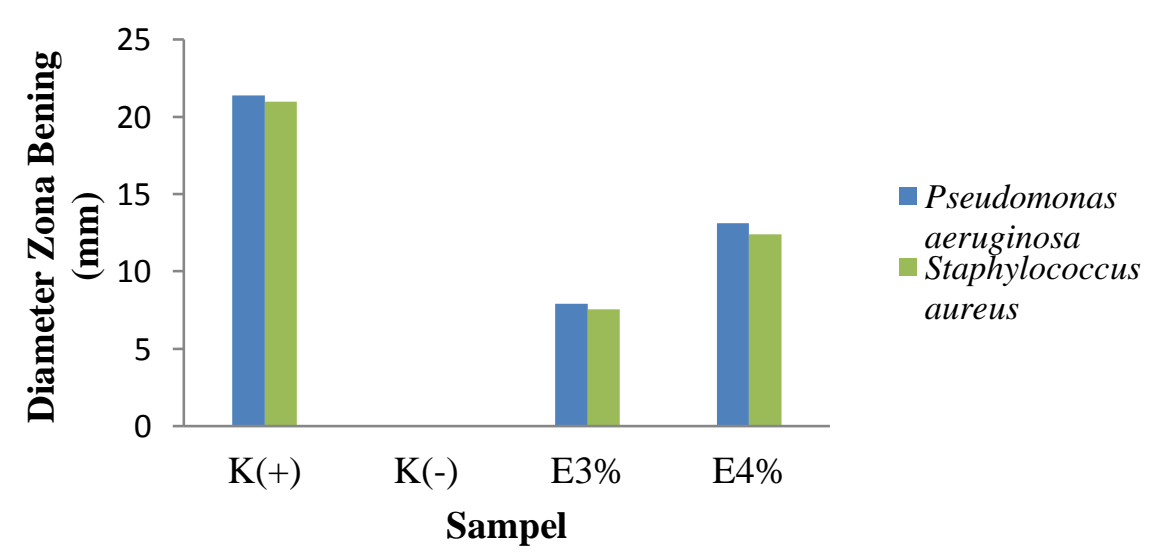

Gambar 1. Daya Hambat Antibakteri dari Ekstrak Kasar Bromelin

Keterangan : $\mathrm{K}(+)=$ Kloramfenikol 1\%, $\mathrm{K}(-)=$ Dapar Fosfat, E3= Ekstrak 3\%, E4= Ekstrak 4\% 
Sediaan salep ekstrak kasar bromelin dibuat menggunakan kosentrasi $4 \%$ yang selanjutnya dilakukan evaluasi. Berdasarkan evaluasi sediaan salep pada Tabel 4, uji organoleptis semua salep dari basis hidrokarbon (F1B\& F2B) maupun salep dari basis Absorpsi( F3B \& F4B) berbentuk setengah padat, memiliki bau khas nanas, dan memiliki warna yang berbeda tergantung dari basis yang digunakan. Jika dilihat dari uji homogenitas,semua sediaan salep homogen. Uji homogenitas dilakukan untuk melihat bahwa dosis dari obat telah tersebar merata dalam sediaan.

Tabel 4. Hasil Evaluasi Sediaan Salep (Organoleptis, Homogenitas, pH dan Iritasi)

\begin{tabular}{|c|c|c|c|c|c|c|}
\hline \multirow{2}{*}{ Formula } & \multicolumn{3}{|c|}{ Organoleptis } & \multirow{2}{*}{ Homogenitas } & \multirow{2}{*}{$\mathbf{p H} \pm \mathrm{SD}$} & \multirow{2}{*}{ Iritasi } \\
\hline & Bentuk & Warna & Bau & & & \\
\hline F1A & $\begin{array}{l}\text { Setengah } \\
\text { padat }\end{array}$ & Putih & Khas & Homogen & 6,3 & Tidak Iritasi \\
\hline F1B & $\begin{array}{c}\text { Setengah } \\
\text { padat }\end{array}$ & Putih & Khas & Homogen & $6,16 \pm 0,05$ & Tidak Iritasi \\
\hline F2A & $\begin{array}{c}\text { Setengah } \\
\text { padat }\end{array}$ & Putih & Khas & Homogen & $6,2 \pm 0,1$ & Tidak Iritasi \\
\hline F2B & $\begin{array}{c}\text { Setengah } \\
\text { padat }\end{array}$ & Putih & Khas & Homogen & $5,96 \pm 0,05$ & Tidak Iritasi \\
\hline F3A & $\begin{array}{l}\text { Setengah } \\
\text { padat }\end{array}$ & $\begin{array}{c}\text { Putih } \\
\text { Kekuningan }\end{array}$ & Khas & Homogen & $6,13 \pm 0,05$ & Tidak Iritasi \\
\hline F3B & $\begin{array}{c}\text { Setengah } \\
\text { padat }\end{array}$ & $\begin{array}{c}\text { Putih } \\
\text { Kekuningan }\end{array}$ & Khas & Homogen & $6,03 \pm 0,05$ & Tidak Iritasi \\
\hline F4A & $\begin{array}{c}\text { Setengah } \\
\text { padat }\end{array}$ & Kuning & Khas & Homogen & $6,13 \pm 0,05$ & Tidak Iritasi \\
\hline F4B & $\begin{array}{c}\text { Setengah } \\
\text { padat }\end{array}$ & Kuning & Khas & Homogen & $5,83 \pm 0,05$ & Tidak Iritasi \\
\hline $\mathbf{F p}$ & $\begin{array}{c}\text { Setengah } \\
\text { padat }\end{array}$ & Putih & Khas & Homogen & $6,33 \pm 0,05$ & Tidak Iritasi \\
\hline Keterangan : & \multicolumn{2}{|c|}{$\begin{array}{l}\text { F1A }=\text { Basis Formula } 1 \\
\text { F1B }=\text { Formula } 1 \\
\text { F2A }=\text { Basis Formula } 2 \\
\text { F2B }=\text { Formula } 2 \\
\text { F3A }=\text { Basis Formula } 3\end{array}$} & \multicolumn{2}{|c|}{$\begin{array}{l}\text { F3B }=\text { Formula } 3 \\
\text { F4A = Basis Formula } \\
\text { F4B = Formula } 4 \\
\text { Fp }=\text { Salep Pembanding }\end{array}$} & & \\
\hline
\end{tabular}

Uji pH dilakukan pada tiap formula salep, diketahui salep yang mengandung enzim bromelin dari bonggol nanasmenggunakan basis hidrokarbon (F1B\& F2B) memiliki pH dengan rentang 5,96-6,3. Sedangkan salep dari basis Absorpsi( F3B\& F4B) memiliki pH 5,83 - 6,13. Akan tetapi formula pembanding (sediaan salep yang berredar dipasaran dengan kandungan zat aktif kloramfenikol 1\%) memiliki $\mathrm{pH}$ yang lebih tinggi yaitu 6,33. Jika dilihat dari hasil pengujian $\mathrm{pH}$ tersebut dapat dikatakan perbedaan basis salep hidrokarbon dan absorpsi tidak mempengaruhi dari nilai $\mathrm{pH}$ sedian salep ekstrak kasar bromelin. Semua sediaan salep telah memenuhi syarat $\mathrm{pH}$ sediaan topikal yang baik, yaitu sama dengan $\mathrm{pH}$ kulit $(4,5-6,5)$. $\mathrm{pH}$ suatu sediaan topikal harus sesuai dengan $\mathrm{pH}$ kulit untuk memperkecil kemungkinan terjadinya iritasi (Naibaho et al., 2013). Enzim bromelin memberikan aktivitas antibakteri pada $\mathrm{pH}$ 4,5 - 9.8 (Abdulrahman Ali, 2015) 


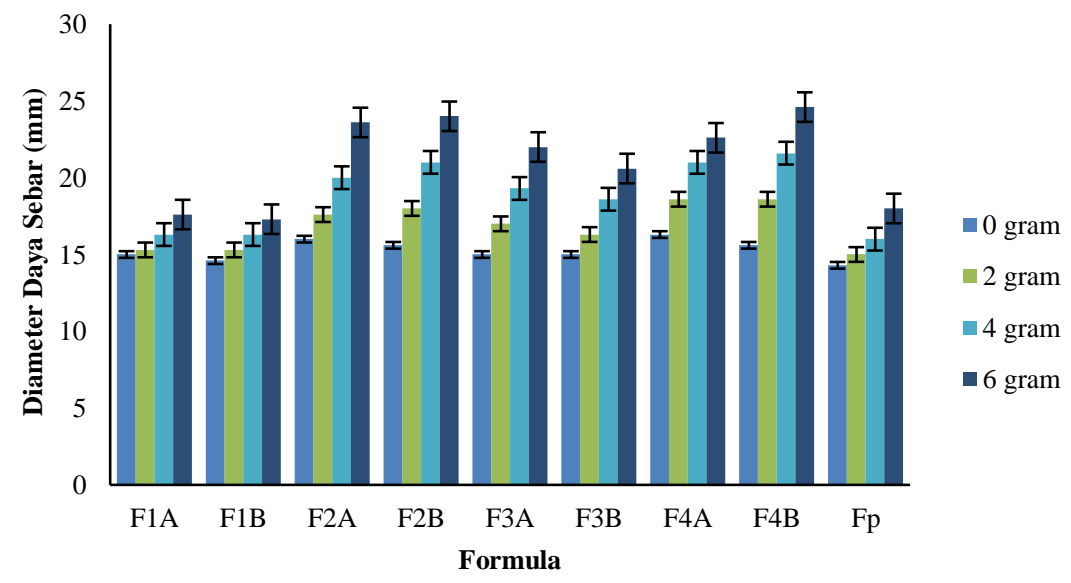

Gambar 2. Hasil Pengujian Daya Sebar Formula Salep Ekstrak Kasar Bromelin menggunakan Beban (2 gram, 4 gram dan 6 gram)

Uji daya sebar untuk setiap salep dengan basis hidrokarbon (F1B \& F2B) dan basis Absorpsi (F3B\& F4B) dilakukan untuk melihat kemampuan penyebaran salep di kulit. Penyebaran salep berpengaruh terhadap proses dan kecepatan difusi zat aktif melewati membran. Semakin besar daya sebar suatu sediaan maka semakin baik dikarenakan semakin luas membran tempat sediaan menyebar yang menyebabkan difusi obat semakin meningkat (Hasyim et al., 2012). Daya sebar salep yang paling baik yaitu pada formula 4 dengan basis absorpsi. Dari pengujian terhadap daya sebar, dapat dilihat dan dibandingkan dengan viskositas nya. Daya sebar suatu sediaan akan berbanding terbalik dengan viskositas karena semakin besar daya sebar maka akan semakin rendah viskositasnya. Sehingga dari 4 formula basis salep, yang memiliki viskositas yang paling rendah dan daya sebar yang paling besar adalah formula 4 dengan basis absorpsi (Gambar 2). Hal ini dikarenakan pada formula 4 mengandung basis dengan jumlah air yang lebih banyak dari basis lainnya.

Tabel 5. Hasil Uji Stabilitas hari ke 28

\begin{tabular}{|c|c|c|c|c|c|}
\hline \multirow[t]{2}{*}{ Suhu } & \multirow{2}{*}{ Formula } & \multicolumn{4}{|c|}{ Pengamatan } \\
\hline & & Bentuk & Warna & Bau & Homogenitas \\
\hline \multirow{5}{*}{$4 \circ C$} & F1B & Setengah Padat & Putih & Khas & Homogen \\
\hline & F2B & Setengah Padat & Putih & Khas & Homogen \\
\hline & F3B & Setengah Padat & Putih Kekuningan & Khas & Homogen \\
\hline & F4B & Setengah Padat & Putih & Khas & Homogen \\
\hline & FP & Setengah Padat & Putih & Khas & Homogen \\
\hline \multirow{5}{*}{ Ruangan } & F1B & Setengah Padat & Putih & Khas & Homogen \\
\hline & F2B & Setengah Padat & Putih & Khas & Homogen \\
\hline & F3B & Setengah Padat & Putih Kekuningan & Khas & Homogen \\
\hline & F4B & Setengah Padat & Putih & Khas & Homogen \\
\hline & FP & Setengah Padat & Putih & Khas & Homogen \\
\hline \multirow{5}{*}{$40 \cdot \mathrm{C}$} & F1B & Terbentuk Dua Fasa & Putih & Tidak Berbau & Tidak Homogen \\
\hline & F2B & Terbentuk Dua Fasa & Putih Kekuningan & Tidak Berbau & Tidak Homogen \\
\hline & F3B & Terbentuk Dua Fasa & Putih Kekuningan & Tidak Berbau & Tidak Homogen \\
\hline & F4B & Terbentuk Dua Fasa & Putih & Tidak Berbau & Tidak Homogen \\
\hline & $\mathbf{F P}$ & Terbentuk Dua Fasa & Putih & Tidak Berbau & Tidak Homogen \\
\hline
\end{tabular}


Selama uji stabilitas yang dilakukan 28 hari, salep dengan tipe basis hidrokarbon (F1B \& F2B)dan basis Absorpsi ( F3B\& F4B) di simpan di tiga suhu yang berbeda. Jika dilihat pada Tabel 5, untuk salep yang disimpan di suhu $4^{\circ} \mathrm{C}$ dan suhu ruangan dikatakan stabil karena tidak terjadinya perubahan bentuk dari sediaan. Sedangkan semua salep yang disimpan di suhu $40^{\circ} \mathrm{C}$ tidak stabil karena terbentuk dua fasa.

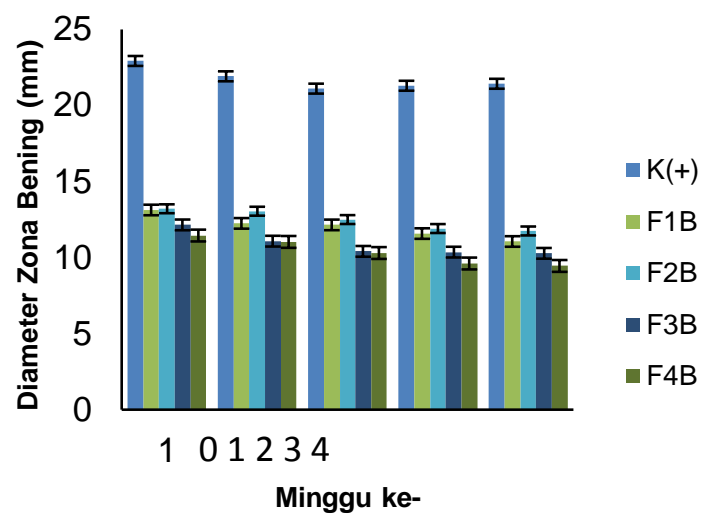

Gambar 3. Daya Hambat Salep Antibakteri Pseudomonas aeruginosa pada suhu 4॰C

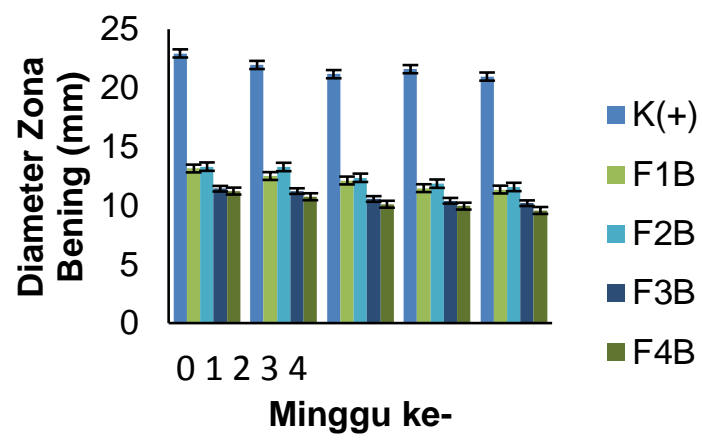

Gambar 4. Daya Hambat Salep Antibakteri Staphylococcus aureus pada suhu 4॰C

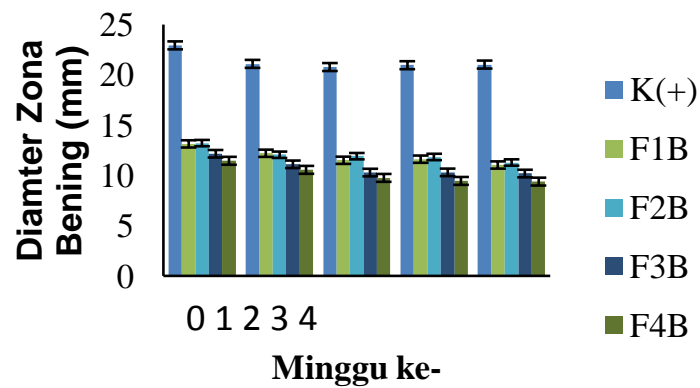

Gambar 5. Daya Hambat Salep Antibakteri Pseudomonas aeruginosa pada suhu ruangan 


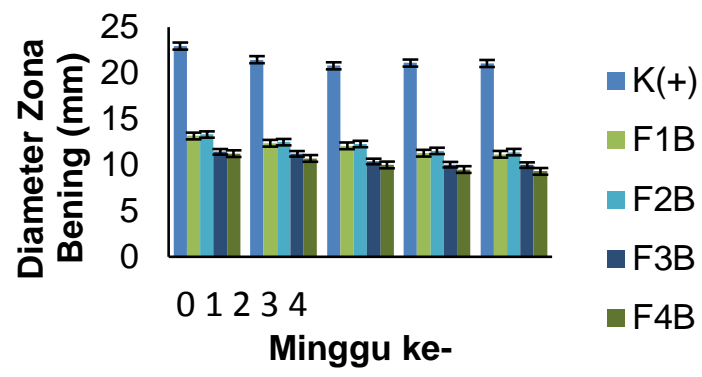

Gambar 6. Daya Hambat Salep Antibakteri Staphylococcus aureus pada suhu ruangan

Hasil penelitian menunjukkan bahwa basis hidrokarbon (F1B \& F2B) memiliki aktivitas antibakteri yang lebih baik dibandingkan dengan basis Absorpsi (F3 \& F4) (Gambar 3-6). Basis hidrokarbon merupakan basis yang baik digunakan untuk sediaan dengan aktivitas sebagai antibakteri karena mengandung komponen air yang lebih sedikit, sedangkan pada basis Absorpsi( F3B \& F4B) yang mengandung komponen air yang lebih banyak sehingga memberikan aktivitas antibakteri yang lebih kecil jika dibandingkan dengan basis hidrokarbon. Hal tersebut dikarenakan air merupakan salah satu media pertumbuhan bakteri. (Yanhendri \& Satya, 2012). Kemampuan aktivitas antibakteri dari enzim bromelin bisa merusak peptidoglikan dari membran bakteri dan mampu mendenaturasi protein yang ada di mebran sehingga bakteri menjadi lisis.(Liliany et al., 2018)

Jika dilihat dari pengaruh suhu nya, salep yang disimpan di suhu $4{ }^{\circ} \mathrm{C}$ memiliki aktivitas yang lebih baik dibandingkan pada suhu ruangan. Hal ini dikarenakan sifat enzim yang lebih baik jika disimpan disuhu dingin, semakin tinggi suhu maka resiko terjadinya denaturasi enzim juga semakin besar (Noviyanti et al., 2012). Basis pada salep tidak dapat membawa zat aktif enzim bromelin jika terjadi denaturasi pada enzim tersebut. Jika dibandingkan antara uji aktivitas ekstrak enzim bromelin dan sediaan salep yang memiliki aktivitas yang lebih baik adalah ektstrak enzim bromelin yang dimurnikan sebagian karena dalam sediaan salep mengandung bahan-bahan tambahan selain zat aktif sehingga memberikan aktivitas antibakteri yang berbeda (Naibahoet al., 2013)

\section{KESIMPULAN}

Basis yang lebih baik digunakan untuk sediaan salep dengan zat aktif ekstrak kasar bromelin dari bonggol nanas adalah basis hidrokarbon (F1B \& F2B). Diantara ke 2 formula salep yang menggunakan basis hidrokarbon yang paling baik pada formula 2B karena formula tersebut memberikan aktivitas antibakteri yang lebih baik terhadap Staphylococcus aureus dan bakteri Pseudomonas aeruginosa.

\section{DAFTAR PUSTAKA}

Abdulrahman Ali, A. (2015). Antimicrobial Effects Of Crude Bromelain Extracted From Pineapple Fruit (Ananas Comosus (Linn.) Merr.). Advances In Biochemistry, 3(1), 1. Https://Doi.Org/10.11648/J.Ab.20150301.11

Ashik Ahamed, A., Vishnu Priya, V., Gayathri, R., \& Geetha, R. V. (2016). Evaluation Of Anti Microbial Activity Of Pineapple Extract Against Selected Microbes. International Journal Of Pharmaceutical Sciences Review And Research, 39(1), 277-278.

Hasyim, N., Pare, K. L., Farmasi, F., Hasanuddin, U., \& Timur, U. I. (2012). Formulasi Dan Uji Efektifitas Ekstrak Daun Cocor Bebek Pada Kelinci. Medical Journal Of Hasanuddin University, 16(2), 89-94. 
Ibrahim, W., \& Mutia, R. (2015). Penggunaan Kulit Nanas Fermentasi Dalam Ransum Yang Mengandung Gulma Berkhasiat Obat Terhadap Lemak Dan Kolesterol Ayam Broiler. 15(1), 20-27.

Liliany, D., Widyarman, A., Erfan, E., Sudiono, J., \& Djamil, M. (2018). Enzymatic Activity Of Bromelain Isolated Pineapple (Ananas Comosus) Hump And Its Antibacterial Effect On $\begin{array}{lllll}\text { Enterococcus Faecalis Scientific Dental Journal, } & 2(2),\end{array}$ Https://Doi.Org/10.26912/Sdj.V2i2.2540

Masri, M. (2014). Isolasi Dan Pengukuran Aktivitas Enzim Bromelin Dari Ekstrak Kasar Bonggol Nanas (Ananas Comosus) Pada Variasi Suhu Dan Ph. Biogenesis, 2(2), 119-125.

Masri, M., \& Biologi, D. J. (2013). Jurnal Biology Science \& Education 2013 Mashuri M.

Nagajyothi, A., Gorantla, N., A, R. P., H, A. A., \& Sreedhar, V. (2014). International Journal Of Chemistry And Formulation And Evaluation Of Herbal Ointments Containing Aqueous Extract Of Acalyphaindica Using Different Types Of Ointment Bases. 2(11), 1276-1280.

Naibaho, O. H., Yamlean, P. V. Y., \& Wiyono, W. (2013). Pengaruh Basis Salep Terhadap Formulasi Sediaan Salep Ekstrak Daun Kemangi (Ocimum Sanctum L.) Pada Kulit Punggung Kelinci Yang Dibuat Infeksi Staphylococcus aureus. 2(02), 27-34.

Noviyanti, T., Ardiningsih, P., \& Rahmalia, W. (2012). Pengaruh Temperatur Terhadap Aktivitas Enzim Protease Dari Daun Sansakng (Pycnarrhena Cauliflora Diels ). 1(1), 31-34.

Rahim,Farida., Aria,Mimi., Aji, N. Purnama. (2011). Formulasi Krim Ekstrak Etanol Daun Ubi Jalar (Ipomoeae Batatas L.) Untuk Pengobatan Luka Bakar. 21-26.

Soares, P. A. G., Vaz, A. F. M., Correia, M. T. S., Pessoa, A., \& Carneiro-Da-Cunha, M. G. (2012). Purification Of Bromelain From Pineapple Wastes By Ethanol Precipitation. Separation And Purification Technology, 98, 389-395. Https://Doi.Org/10.1016/J.Seppur.2012.06.042

Yanhendri, \& Satya, W. Y. (2012). Berbagai Bentuk Sediaan Topikal Dalam Dermatologi. Cdk-194, $39(6), 423-430$. 